\title{
Multiomic immune clockworks of pregnancy
}

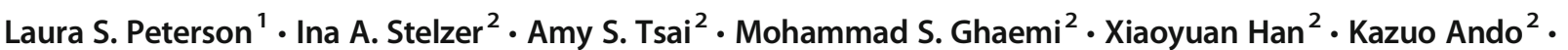 \\ Virginia D. Winn ${ }^{3} \cdot$ Nadine R. Martinez $^{3} \cdot K_{\text {Kevin Contrepois }}^{4,8} \cdot$ Mira N. Moufarrej $^{5} \cdot$ Stephen Quake $^{5}$. \\ David A. Relman ${ }^{6,7}$ • Michael P. Snyder ${ }^{8}$. Gary M. Shaw ${ }^{1} \cdot$ David K. Stevenson ${ }^{1} \cdot$ Ronald J. Wong ${ }^{1} \cdot$ Petra Arck $^{9}$. \\ Martin S. Angst ${ }^{2} \cdot$ Nima Aghaeepour $^{2} \cdot$ Brice Gaudilliere $^{2}$ (D)
}

Received: 26 July 2019 / Accepted: 31 October 2019 / Published online: 4 February 2020

(C) The Author(s) 2019

\begin{abstract}
Preterm birth is the leading cause of mortality in children under the age of five worldwide. Despite major efforts, we still lack the ability to accurately predict and effectively prevent preterm birth. While multiple factors contribute to preterm labor, dysregulations of immunological adaptations required for the maintenance of a healthy pregnancy is at its pathophysiological core. Consequently, a precise understanding of these chronologically paced immune adaptations and of the biological pacemakers that synchronize the pregnancy "immune clock" is a critical first step towards identifying deviations that are hallmarks of peterm birth. Here, we will review key elements of the fetal, placental, and maternal pacemakers that program the immune clock of pregnancy. We will then emphasize multiomic studies that enable a more integrated view of pregnancy-related immune adaptations. Such multiomic assessments can strengthen the biological plausibility of immunological findings and increase the power of biological signatures predictive of preterm birth
\end{abstract}

Keywords Pregnancy $\cdot$ Preterm birth $\cdot$ Prematurity $\cdot$ parturition $\cdot$ multiomics $\cdot$ Immunology $\cdot$ Cytomics $\cdot$ Transcriptomics · Proteomics $\cdot$ Metabolomics $\cdot$ Microbiome $\cdot$ Mass cytometry

\section{Introduction}

For the establishment, maintenance, and completion of mammalian pregnancy, the maternal immune system must adhere to a precise schedule. During 9 months, dynamic local and

Martin S. Angst, Nima Aghaeepour, and Brice Gaudilliere are co-senior authors.

This article is a contribution to the special issue on Preterm birth: Pathogenesis and clinical consequences revisited - Guest Editors: Anke Diemert and Petra Arck

Brice Gaudilliere

gbrice@stanford.edu

1 Division of Neonatal and Developmental Medicine, Department of Pediatrics, Stanford University School of Medicine, Stanford, CA, USA

2 Department of Perioperative and Pain Medicine, Stanford University School of Medicine, Stanford, CA, USA

3 Department of Obstetrics and Gynecology, Stanford University School of Medicine, Stanford, CA, USA

4 Stanford Metabolic Health Center, Stanford University School of Medicine, Stanford, CA, USA systemic immune changes occur that confer tolerance to the semi-allogenic fetus while protecting the mother against invading pathogens. The appropriate execution of these important events requires a tightly regulated immunologic timeline governed by a complex system of immune pacemakers.
5 Department of Bioengineering, Stanford University School of Engineering, Stanford, CA, USA

6 Department of Medicine, Stanford University School of Medicine, Stanford, CA, USA

7 Infectious Diseases Section, Veterans Affairs Palo Alto Health Care System, Palo Alto, CA, USA

8 Stanford Center for Genomics and Personalized Medicine, Department of Genetics, Stanford University School of Medicine, Stanford, CA, USA

9 Department of Obstetrics and Fetal Medicine, University Medical Center Hamburg-Eppendorf, Hamburg, Germany 
Severe pregnancy complications, such as preterm labor and preeclampsia, can result when these immunological adaptations are disrupted [41, 144].

Over six decades of research have contributed to our current understanding of the chronology of feto-maternal immune adaptations during pregnancy [107], and the mechanisms of maternal immune tolerance to the developing fetus have been extensively reviewed $[8,9,79,110-112,181]$. However, the feto-maternal immune system does not evolve in isolation but rather as a component of a complex network of endocrine, metabolic, and microbiome adaptations that interact with signals from the fetus and the placenta in a timely, coordinated manner [144]. Understanding this immune clock is of paramount importance when addressing the problem of prematurity, as a preponderance of evidence has linked immune dysregulation with not only preterm labor but also diseases of pregnancy such as intrauterine growth restriction and preeclampsia, which are major indications for preterm delivery $[21,41,63,144]$. An integrated examination of the factors that influence the programming of immune adaptations during gestation is thus essential to advance our knowledge of both healthy and pathological pregnancies (Fig. 1).
The recent advent of high-content transcriptomic, epigenomic, proteomic, and cytomic technologies has provided powerful means to capture the complexity of multiomic adaptations during pregnancy $[2,3,18,50,54,55,179]$. Specifically, a network of interrelated immune features that are chronologically regulated over the course of gestation has recently been demonstrated [2]. In this review, we will focus on the fetal, placental, and maternal pacemakers that program this immune clock of pregnancy and highlight recent technological advances that allow an integrated, multiomic assessment of immunological events involved in the natural chronology of pregnancy.

\section{Feto-placental pacemakers programming the immune clock of pregnancy}

Before promoting the concept of feto-placental pacemakers, a few characteristics of human placentation and trophoblast differentiation should be elucidated (Fig. 2a, b). Beginning with adherence of the blastocyst to the uterine wall at days $7-8$ after fertilization, trophoblasts (cells of fetal origin that ultimately comprise the placenta) proliferate and invade the uterus,
Fig. 1 Need for longitudinal, multiomic profiling studies to understand immunological adaptations in healthy and pathologic pregnancies. An integrated examination of the factors that influence the timing of immune adaptations during pregnancy will be key to allowing determination of normal immunological variations in healthy pregnancies (lefthand, blue) and identification of deviations predictive of pathological pregnancy outcomes (righthand, orange)

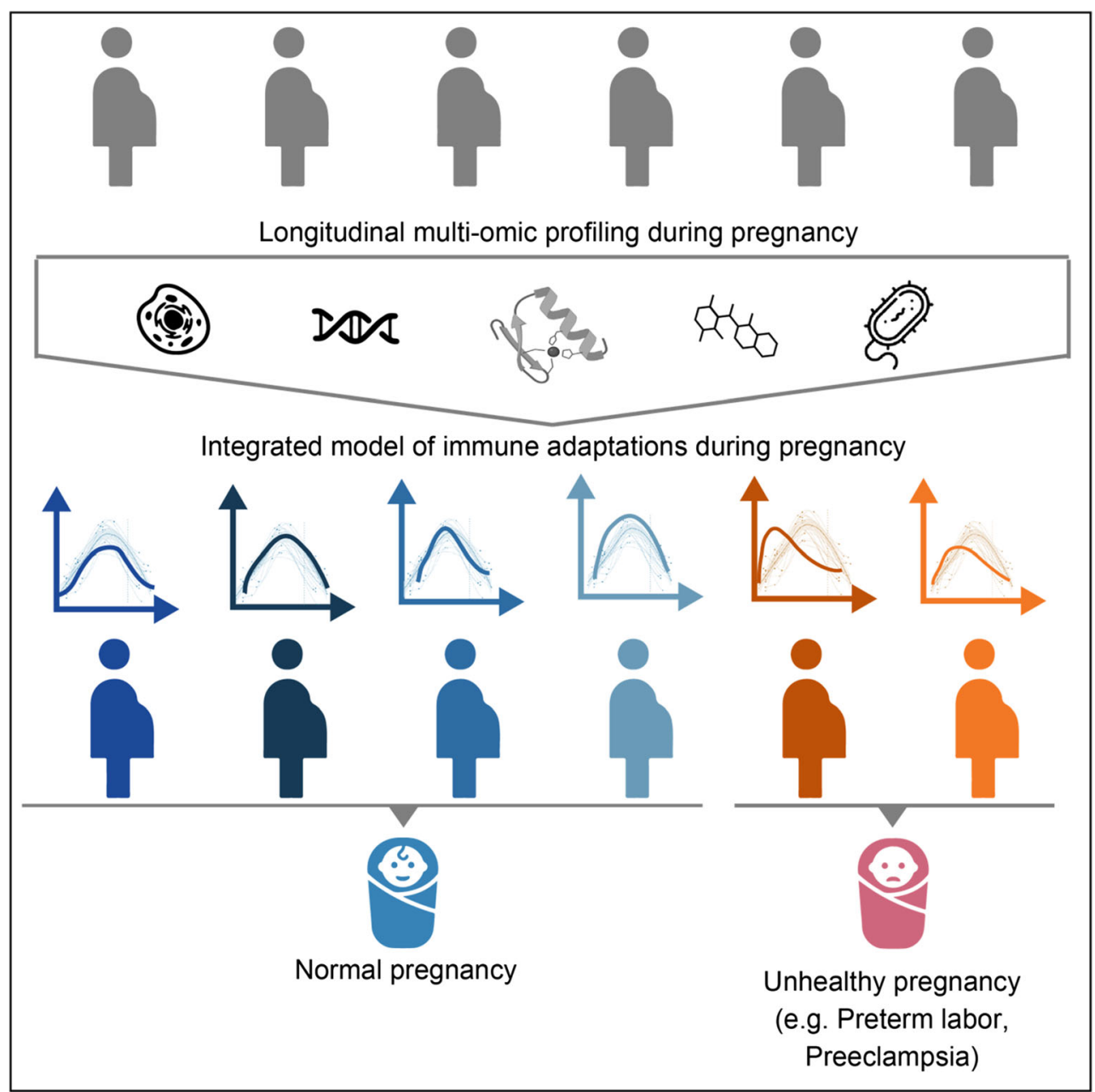




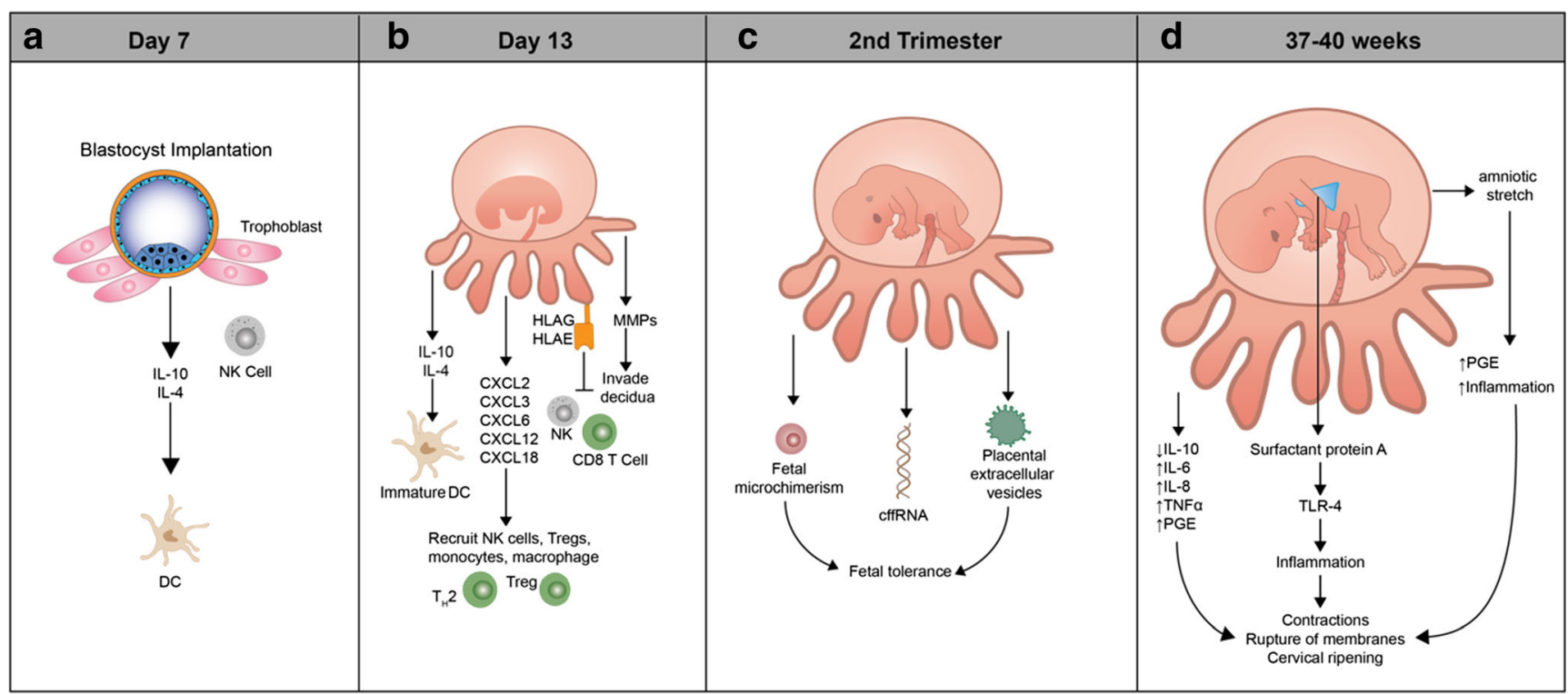

Fig. 2 Contribution of the embryo, fetus, and trophoblasts to the programming of immune adaptations during pregnancy. a The blastocyst implants into the endometrium where it induces decidualization and begins interacting with local immune cells, such as DCs and NKs. b Trophoblasts invade the decidua and secrete cytokines, chemokines (chemokine (C-X-C motif), ligands (CXCL), and matrix metalloproteinases (MMPs) that recruit maternal immune cells and allow for remodeling of decidua/uterus. Specialized HLA molecules on trophoblasts inhibit $\mathrm{CD}^{+} \mathrm{T}$ cell and $\mathrm{NK}$ cell cytotoxicity. A tolerogenic milieu is fostered with Th2-polarized cells, immature dendritic cells, and

triggering the differentiation of local stromal cells into glycogen-rich decidual cells and remodeling of the uterine environment, including transformation of the uterine spiral arteries into thin walled vessels that facilitate exchange of nutrients and metabolites between mother and fetus [51].

\section{Local immune programming by the trophoblasts}

Trophoblasts are key immune pacemakers. Early in pregnancy, they promote an inflammatory niche that is necessary for remodeling of the uterus to accommodate the placenta and provide a rich blood supply for the growing fetus. Approximately 2 weeks after conception, trophoblastsincluding cytotrophoblasts (those that remain connected to the placental villi) and extravillous trophoblasts (those that break away from the main body of the placenta) - invade and remodel local tissues by secreting matrix metalloproteinases and specialized extracellular matrix proteins (e.g., fetal fibronectin) in order to promote placentation (Fig. 2b) [51]. These trophoblasts also secrete chemokines to recruit maternal innate (monocytes, macrophages, and natural killer cells) and adaptive immune cells (including a restricted subset of CD4+ and CD8+ T cells and regulatory T cells (Treg)) (Fig. 2b) [27, $51,64,139,194,200]$. Simultaneously, there is proliferation of resident tissue leukocytes, particularly decidual natural killer (dNK) cells and decidual dendritic cells (dDCs) [9].
Treg cells. c The fetus and placenta modulate the peripheral immune system to enhance fetal tolerance. Fetal microchimerism, cell-free fetal (cff)DNA, and placental extracellular vesicles enter maternal circulation and either promote systemic tolerance (exosomes) via mechanisms such as induction of fetal-specific regulatory $\mathrm{T}$ cells (Treg) or contribute to pathologic inflammation in diseases of pregnancy (microparticles). d Signals of fetal maturity, such as surfactant protein A production by fetal lungs and stretch of the amniotic membranes, trigger inflammation, leading to the common pathway of parturition

Given their location at the maternal-fetal interface, trophoblasts provide a sentinel line of defense that protects fetal tissues from maternal cytotoxic immune cells, thereby safeguarding against premature termination of pregnancy. For example, human trophoblasts are known to express the nonclassical type 1 human leukocyte antigens (HLA)-E and HLA-G as well as a classical HLA-C antigen that inhibits rather than activates cytotoxic $\mathrm{NK}$ and $\mathrm{CD}^{+} \mathrm{T}$ cells $[30,48$, $82,89]$. Several in vitro studies using human and mouse cells also suggest that trophoblasts impart an immature phenotype to local dDCs that encourages differentiation of Tregs and a tolerogenic Th2-polarized environment with high levels of classically anti-inflammatory cytokines, such as IL-10 [97, $133,156,169,170,199]$.

\section{Immune programming by circulating fetal material}

In conjunction with local immune adaptations regulated by trophoblasts, there is emerging evidence for the immunomodulatory role of circulating cellular and noncellular material derived from the feto-placental unit. We will briefly review how circulating extracellular vesicles (EVs), cell-free fetal DNA (cffDNA), and fetal microchimeric cells may serve as immune pacemakers of pregnancy (Fig. 2c).

As the placenta grows, diverse membrane-derived EVsexosomes $(\sim 50-150 \mathrm{~nm})$, microvesicles $(200 \mathrm{~nm}-2 \mu \mathrm{m})$, and 
apoptotic bodies - are released by feto-placental tissues, potentially stemming from cytotrophoblasts, syncytiotrophoblasts, and placental mesenchymal stem cells. Concentrations of EVs increase linearly as pregnancy progresses, suggesting their role as pacemakers of pregnancy $[116,137,158,160]$. These EVs play a role in intercellular communication by serving as vehicles for transfer of membrane and cytosolic fetal proteins, lipids, and micro (mi)RNA [108]. Recent studies have attributed immunosuppressive faculties to exosomes, such as induction of apoptosis in activated lymphocytes, impairment of NK cytotoxicity, and secretion of TGF $\beta$ and PDL-1, thereby encouraging Treg differentiation [109].

Microparticles, on the other hand, are formed in the context of physiological oxidative stress as a mild pro-inflammatory response that might counterbalance the effect of the immunosuppressive exosomes in the placental environment $[109,178]$. Variations in the concentration and bioactivity of EVs have been implicated in pregnancy pathologies, including preeclampsia and preterm birth $[26,84,87,94,104,158,178]$. A decrease in immunosuppressive exosomes associated with preterm birth and shifts of molecular cargo towards pro-coagulant and proinflammatory factors in trophoblast-derived EVs in preeclampsia are suggestive of their contribution to a modulated maternal immune adaptation in complicated pregnancies, although causation has not been demonstrated [114]. Shortcomings in resolution and sensitivity of techniques to quantitatively and qualitatively assess nano-scale EVs have so far been an obstacle to the understanding of the biogenesis and activity of their various forms; however, a number of new technologies, such as combined differential ultracentrifugation, transmission electron microscopy, and nanoparticle tracking analysis have emerged that allow for their isolation, examination of morphology, and analysis of size distribution and concentration [78, 113, 193].

Apoptotic trophoblasts are also an important source of cellfree fetal DNA (cffDNA) released into the maternal circulation. The plasma concentration of cffDNA increases exponentially as the placenta ages and the number of apoptotic trophoblasts increases $[47,100]$. cffDNA is hypomethylated compared with adult cell-free DNA and is therefore an agonist of Toll-like receptor (TLR)-9, which canonically responds to hypomethylated bacterial and viral DNA [33, 187]. In pregnant mice, evidence suggests that injection of hypomethylated DNA leads to TLR-9 agonism and can precipitate labor, while blocking TLR-9 activation rescues these mice from preterm delivery [180]. Although the immune-modulatory effect of cffDNA has not been demonstrated in humans, these findings suggest that cffDNA may participate in the programming of TLR-dependent immune responses required for maternal immune adaptations implicated in the onset of labor - both at term when cffDNA levels peak, and potentially at preterm in the setting of other derangements. However, this remains speculative, and more human studies are needed to validate the role of cffDNA in the immunology of human pregnancy.
In addition to noncellular fetal material shed into the maternal circulation, another phenomenon that likely contributes to maternal immune modulation is the transfer and systemic seeding of small numbers of intact fetal cells, termed fetal microchimerism. The frequency of these cells, which originate from an array of different fetal tissues, including hematopoietic, progenitor, and tissue-specific cell types, increases in a gestational-age-dependent manner, and they are likely immunologically active. As early as the second trimester in humans [70, 90, 141], nonhuman primates [74], and mice [77], fetal cells are detectable in maternal blood and tissues. These cells increase with advancing gestational age, peak at parturition, and sharply decline postpartum [11, 53, 188]. Remarkably, these cells have the capacity to persist long-term after pregnancy, and may influence a variety of disease states including autoimmunity and graft-versus-host disease in transplant patients $[16,53,141]$.

Despite agreement on the existence of fetal microchimeric cells, less is known about their function during pregnancy, in part due to the lack of an agreed-upon method to isolate these extremely rare fetal cells [76]. The accumulation of these genetically foreign cells in the maternal periphery, however, parallels the enhanced maternal immune tolerance of the fetus, e.g., systemic expansion of maternal Tregs with specificity to paternal-fetal antigens. As such, it is biologically plausible that fetal cells contribute to tolerogenic environment necessary to carry pregnancy to term.

Fetal material that is continuously shed into maternal circulation and tissues is likely a potent contributor to one of the pillars of maternal immune programming: the differentiation and expansion of peripheral Tregs. These immunoregulatory cells, which, at least in mice, have been shown to be specific to fetal antigens, undergo gestational-age-dependent expansion and contraction $[6,32,37,73,159]$. The trajectory of peripheral Tregs has been delineated by Somerset et al. who quantified levels of peripheral Tregs $\left(\mathrm{CD} 4^{+} \mathrm{CD} 25^{+}\right)$in human pregnancies via cross-sectional analysis of samples acquired from nonpregnant women and women in each trimester. They found that Tregs increased 1.5 -fold over the nonpregnant state in the first trimester, peaked at 2.5 -fold in the second trimester, and decreased slightly to 2-fold in the third trimester [167]. Since then, at least 14 different studies have confirmed an increase in Tregs during human pregnancy [73]. The function of these pregnancy-induced Tregs has been well studied in mouse models. For instance, one group demonstrated that that depletion of $\mathrm{CD} 4{ }^{+} \mathrm{CD} 25^{+}$Treg cells in pregnant mice led to pregnancy loss with an impressive $100 \%$ penetrance [6], a finding corroborated by a separate group that demonstrated that even partial transient ablation of Forkhead Box P3 $(\text { FoxP3 })^{+}$Tregs in mice led to a 10 -fold increase in fetal resorption and $70 \%$ decrease in live-born pups [153]. Vice versa, adoptive transfer of Tregs can rescue pregnancy failure in mouse models of spontaneous abortion and infertility [190, 
191, 197]. In humans, women with lower levels of Tregs may be more prone to spontaneous abortions and preterm labor [161]. These studies support the concept that Tregs are essential in ensuring the appropriate duration of gestation and represent an important component of the pregnancy immune clock.

\section{The feto-placental unit in the timing of parturition}

As pregnancy approaches term at 37 to 40 weeks' gestation, the immune function of the feto-placental unit evolves to enable inflammatory changes that facilitate the onset of labor and parturition (Fig. 2d). Evidence suggests that local indicators of fetal maturity trigger the maternal immune system to undergo a shift towards a pro-inflammatory state. For instance, surfactant protein A, produced by mature fetal lung tissue, is a TLR-4 agonist and stimulator of cyclooxygenase (COX)-2 activity and prostaglandin (PG)E2 production [34]. Mechanical stretch of the amnion and myometrium by the growing fetus may also induce pro-inflammatory signals that can precipitate labor. In nonhuman primates, inflation of a balloon within the amniotic cavity increased maternal plasma interleukin (IL)-1 $\beta$, tumor necrosis factor (TNF) $\alpha$, IL-8, and IL-6 and prompted uterine contractions [188]. It is well known that these pro-inflammatory cytokines TNF $\alpha$ and IL-1 $\beta$ and production of prostaglandins are strongly associated with active labor in both mice and humans $[65,67,106,151]$.

The switch in immune phenotype of the feto-placental unit from predominantly tolerogenic to pro-inflammatory works in synchrony and synergistically with other immune, developmental, and environmental inputs to initiate a cascade of events characterized by recruitment of maternal and fetalderived pro-inflammatory immune cells to the uterine myometrium, maternal cervix, and fetal chorioamniotic membranes $[52,103,105,120,183]$. Although the complex interplay between these signals and cells is incompletely understood, the end result is the common pathway of parturition: rupture of membranes, cervical ripening, and uterine contractions [150].

\section{Maternal pacemakers programming the immune clock of pregnancy}

On the maternal side of the maternal-fetal interface, the local stromal environment, known as the decidua, is an immunologically active site where decidual stromal cells co-exist with maternal immune cells in a tightly regulated relationship that evolves as pregnancy progresses. The importance of the decidua in regulating the chronology of immune adaptations during pregnancy has been extensively reviewed elsewhere $[9,66,81,91,98,118]$ and is summarized in Fig. 3. Here, we will focus on maternally derived endocrine, metabolic and microbial immunological pacemakers - elements that can be readily assessed during pregnancy in the peripheral blood.

\section{Endocrine regulation of immune responses in pregnancy}

The discovery that sex hormones have the capacity to regulate the immune system can be traced as far back as the nineteenth century when Italian biologists noted that castration caused thymic atrophy [24]. The plasma levels of sex hormones such as progesterone, estrogen, and human chorionic gonadotropin (hCG) follow a well-defined timetable during gestation and are perhaps the best studied pacemakers of pregnancy (reviewed [7, 44, 58, 125, 131, 171]). Here, we will examine the immunomodulatory roles of these hormonal pacemakers. Other hormones, including prolactin and corticotrophin releasing hormone, likely contribute to the regulation of the immune system of pregnancy; however their immunomodulatory role is less well established.

Progesterone-which rises throughout human pregnancy before dipping slightly prior to parturition - is a keystone pacemaker for pregnancy [51, 125, 185]. Progesterone influences the pregnancy timeline through its immunomodulatory activity, which is mediated via four main mechanisms: (1) direct communication with immune cells via its nuclear receptors, progesterone receptor (PR)-B and PR-A, (2) signaling through its membrane progesterone receptors (mPR), (3) promiscuous binding to the glucocorticoid receptor, and/or (4) inducing transcription of the paracrine hormone Progesterone Induced Blocking Factor (PIBF) [10, 12, 14, $15,92,122,132,172]$. Although progesterone's role in the immune system remains an area of investigation, the general consensus is that, at least up until the time of parturition, progesterone is a critical factor in the maintenance of an immunotolerant state and of myometrial quiescence. Several mechanisms have been proposed as to how these important tasks are accomplished, and are detailed Fig. 4b. Immediately preceding the onset of labor, there is a decrease in progesterone's pro-tolerant influence. Plasma progesterone levels in mice and other sub-primate mammals drop precipitously prior to labor, and this drop can trigger labor [195]. In humans, although circulating progesterone does not decline significant$\mathrm{ly}$, there is evidence of a functional progesterone withdrawal preceding labor; for instance, there is a change in expression of nuclear progesterone receptor isoform PR-B (antiinflammatory) to PR-A (pro-inflammatory) in myometrial cells and production of inhibitory microRNAs (e.g., miR200) $[46,69,140]$ (Fig. 4c).

Estrogen is also immunomodulatory, and its levels undergo gestational-age-dependent changes. The effects of estrogen are predominantly mediated by three active forms: estrone (E1), estradiol (E2), and estriol (E3) - the latter of which is produced exclusively by the placenta (Fig. 4a, b) [46]. The 


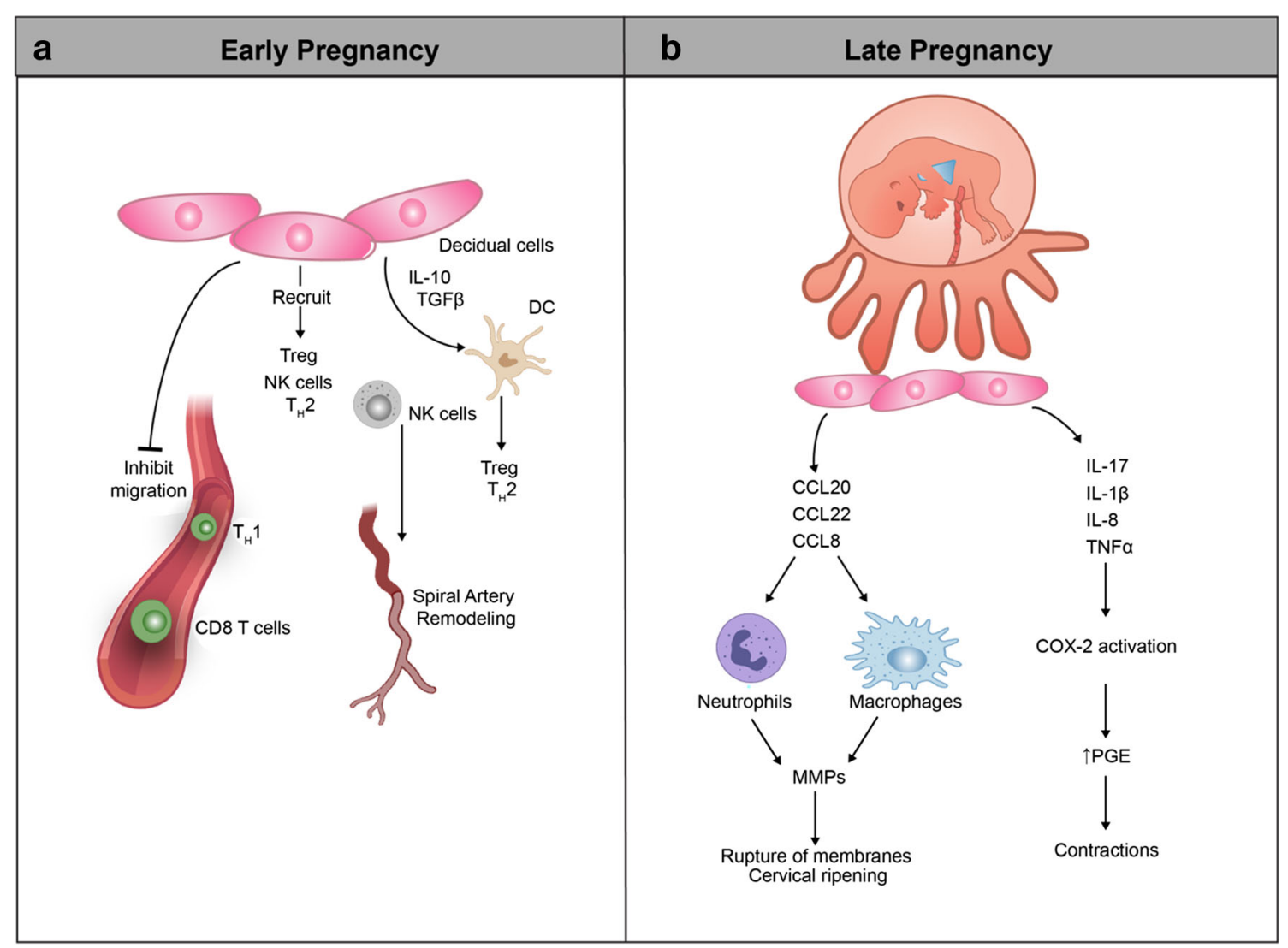

Fig. 3 Contribution of maternal decidua to the programming of immune adaptations during pregnancy. a Decidual stromal cells condition the local immune environment by secreting chemokines and cytokines that recruit and activate specialized maternal immune cells (Tregs, Th2 cells, NK cells, restricted subsets of $\mathrm{T}$ cells) and chemoattract invading trophoblasts. Several studies support that this decidual chemokine/ cytokine profile is under gestational-age-dependent control and that disruption of the normal profile affects pregnancy outcomes and the timing of parturition $[115,139,192,200]$. b The decidua prompts inflammatory changes that contribute to the onset of labor by expressing chemokines and cytokines that contribute to inflammatory cell infiltration, prompting myometrial contractions via production of prostaglandins and inflammatory cytokines (particularly, IL-1 $\beta$ and $\mathrm{TNF} \alpha$ ) and promoting cervical ripening and rupture of chorioamniotic membranes via release of MMPs [45, 57, 62, 118, 120, 142, 151, 183, 189]

studied than that of progesterone or estrogen, evidence suggests that hCG may interact with immune cells in order to foster placentation (e.g., by stimulating proliferation of dNK cells) $[75,184]$ and to establish a local immune tolerant state (e.g., by inducing a tolerogenic phenotype in DCs in mice) [38, 162-164] (Fig. 4a). However, not all studies have produced consistent results, and evidence for the immunomodulatory role of $\mathrm{hCG}$ in humans is still lacking.

One important hurdle in studying endocrine-immune crosstalk is the difficulty in determining whether a hormone acts on all cells or only on one subset, which subsequently interacts with others. Thiele et al. recently attempted to address this in murine pregnancy by studying targeted knock-outs of the nuclear progesterone receptor PR-B in DCs [182]. They found decreased frequency of uterine Tregs during pregnancy and mild fetal growth restriction, but there was no change in rates of pregnancy or timing of parturition, suggesting that nuclear progesterone 


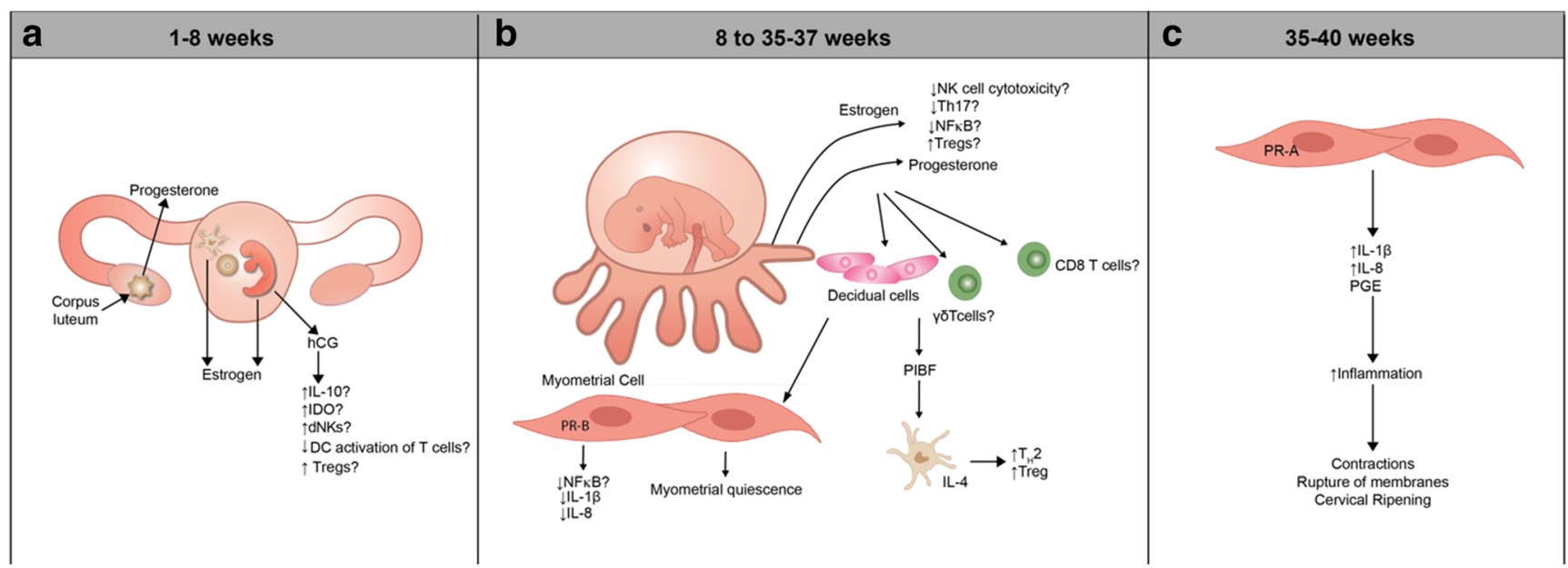

Fig. 4 Endocrine regulation of immune adaptations during pregnancy. a In the first 8 weeks of human pregnancy, progesterone is produced predominantly by the corpus luteum; hCG is produced by the early embryo; and the placenta is the major source of estrogen (as it is for the duration of pregnancy) [125]. Early in pregnancy, hCG may interact with the immune system to promote vascular remodeling via dNK cells and to promote an immature DC phenotype that encourages Th2 and Treg differentiation. b Nuclear progesterone receptors (PR-B or PR-A) are found in decidual cells, myometrial cells, and a subset of immune cells (e.g., CD4 and CD8 T cells) [12, 28, 69, 83, 128, 172, 177]. Progesterone binding to PR-B induces transcription of PIBF. In humans and mice, progesterone (either directly or via PIBF) contributes to the arrest of dDC maturation in vitro, which fosters a Th2 environment and encourages differentiation and expansion of Tregs [22, 95, 131, 165, 181]. In vitro studies in humans have suggested that progesterone

signaling in DCs is involved in the induction of immune tolerance during pregnancy but that this signal alone does not necessarily affect the timeline of pregnancy [182]. Further studies on the timing and cell specificity of the effect of hormones on the maternal immune system are needed in order to adequately decipher their complex role in the immune clock of pregnancy.

\section{Metabolic regulation of immune responses in pregnancy}

The interplay between metabolism and immunity is well established [86, 119, 123, 124, 155]. Perhaps relatedly, a healthy maternal metabolic status and energy balance are essential for the development and maintenance of pregnancy. In healthy pregnancies, there is a natural shift in metabolic status from an energy-storing anabolic state in the first two trimesters to a catabolic state in the third trimester, thereby providing substrate for the rapidly developing fetus near term and allowing for the accretion of fetal energy stores in preparation for extrauterine life [198]. Metabolic dysfunction, as seen in malnutrition or obesity, is associated with adverse pregnancy outcomes, including infertility, pregnancy loss, preeclampsia, preterm labor, and fetal growth abnormalities [5]. Because significant crosstalk exists between metabolic and immune decreases NK cell cytotoxicity and renders NK cells more susceptible to apoptosis $[12,44,171,173]$. Estrogen may impair NK cell cytotoxicity, discourage Th17 differentiation, encourage peripheral Treg differentiation, and inhibit NF-kB-mediated transcription [1, 31, 68, 72, 129-131, 134, 176, 186]. c At parturition, progesterone's effects on human myometrial cells shifts from anti-inflammatory/pro-quiescent to pro-inflammatory/pro-contractile. PR-B inhibits the pro-inflammatory transcription factor NF-KB in human myometrial cells, thereby decreasing production of pro-inflammatory cytokines such as IL-1 $\beta$ and IL-8, which are implicated on the onset of labor. Immediately preceding labor, decreased myometrial expression of PR-B and increased expression of PR-A are associated with production of IL- $1 \beta$ and IL- 8 by myometrial cells [177]. This change in nuclear progesterone receptor profile may represent a functional progesterone withdrawal in humans. IDO, indoleamine 2,3-dioxygenase

systems, a comprehensive characterization of a gestational immune clock therefore requires a careful study of maternal metabolism [181].

Gestational-age-dependent changes in adipose tissue have important immunological implications. Adipokines produced by adipose tissue, such as leptin, adiponectin, resistin, and vasfatin, are immunologically active [96]. Leptin is particularly well studied in the context of pregnancy. This hormone, produced by both adipocytes and the placenta, increases linearly throughout gestation, and abnormally elevated leptin levels have been consistently associated with pathologic pregnancies, including gestational diabetes mellitus and preeclampsia [36, 157]. The leptin receptor is found on both innate and adaptive immune cells, and a variety of early observational in vitro studies have linked it with pathologic inflammation (such as that seen in autoimmune diseases and chronic obesity), differentiation of pro-inflammatory Th17 cells, and inhibition of the differentiation of Tregs [40, 127, 138]. These studies suggest a possible role for leptin at the interface of metabolic and immunologic disturbances implicated in pregnancy. Given that leptin levels increase with advancing gestation, it is tempting to hypothesize that accumulation of this hormone may contribute to the timely shift towards a pro-inflammatory state in late gestation. However, the role of leptin in immune regulation and temporal dynamics 
during pregnancy is predominantly supported by correlative studies and speculation, and future studies are needed.

\section{Microbiome regulation of immune responses in pregnancy}

The vast repertoire of commensal organisms that colonize our bodies play a critical role in modulating human physiology by affecting the endocrine, metabolic, nutritional, and immune systems $[29,35]$. While relatively few studies have examined this question in the context of pregnancy, evidence from studies in the nonpregnant state suggest that commensal organisms are involved in the programming of peripheral and local immune tolerance via a plethora of mechanisms, including endotoxin tolerance $[17,168]$ and induction of Tregs by bacterial metabolites $[93,166]$. Several longitudinal studies have recently investigated the changes in maternal vaginal and gut microbiota during pregnancy, which are potential contributors to the immune clock of pregnancy $[42,88,102,147,175]$. These studies have yielded incongruous results, which likely reflect differences in demographic and/or genetic factors between studies. However, in general, studies have identified increased constancy (i.e., decreased beta diversity) of site-specific microbiomes in the pregnant vs nonpregnant state $[42,88,102,135,136$, 175]. Overall, the role of the microbiome in the immunomodulation of pregnancy is therefore likely one of providing immunologic stability. As such, disruption of these microbial profiles may be associated with abnormal immune adaptations during pregnancy that could affect the normal immune clock. Indeed, local infections such as chorioamnionitis and bacterial vaginosis are strongly associated with preterm birth $[19,49,56,71]$. Attempts to identify a vaginal microbial signature predictive of preterm birth have yielded conflicting results: some groups have identified differences in the vaginal microbiome [23, 80, 174], while other groups have not [148]. Novel approaches to analyze the microbiome may be helpful in reconciling some of the incongruencies between studies [59]. Of note, a placental microbiome has also been postulated, but its existence has been called into question recently and will not be discussed here $[13,126]$.

\section{Towards an integrated, multiomic modeling of immune adaptations during pregnancy}

The studies highlighted thus far emphasize that immune system adaptations during pregnancy occur within larger regulatory networks that integrate inputs from the fetus, the mother, and their environment (Fig. 5). It has heretofore been difficult to synthesize what we know about these diverse inputs in order to gain a holistic understanding of the factors governing the progression of both healthy and pathologic pregnancies. In the past decade, the exponential development of high-content -omic technologies has allowed the simultaneous assessment of the cellular (cytomic), transcriptomic (encompassing the assessment of RNA as well as changes in the microbiome), proteomic, and metabolomic components of regulatory networks in a variety of medical conditions ranging from diabetes to pregnancy $[39,55,152,179]$. A strength of these multiomic integrative approaches is the potential to incorporate large and complex bodies of information into a universal view of the biological states being studied, and they carry substantial clinical potential. For instance, Rose et al. recently demonstrated the ability of a multiomic (including transcriptomic, proteomic, immunomic, and metabolomic) approach in combination with clinical data to accurately predict the development of certain diseases such as type 2 diabetes and atherosclerotic cardiovascular disease across an 8-year period [152]. Similar studies in the field of pregnancy and its complications, such as preeclampsia, have yielded exciting early results, and many more such studies are underway [63].

Mass cytometry, or cytometry by time of flight mass spectrometry (CyTOF), has emerged as a powerful tool for the high-dimensional analysis of immune cell adaptations during pregnancy. CyTOF is a high-parameter flow cytometry technique which uses antibodies conjugated to metal isotopes rather than fluorescent reporters to quantify over 50 parameters on a cell-by-cell basis. In a recent study, a mass cytometry immune-assay was applied to simultaneously quantify over 900 immune cell frequencies and their functional states in longitudinal blood samples collected during pregnancy [2]. The analysis identified communities of immune features that tracked gestational age with remarkable accuracy, providing a single cell assessment of the peripheral immune clock of pregnancy. Among the key components of the multivariate immune clock model was a progressive increase in Signal Transducer and Activator of Transcription (STAT) 5 signaling in several subsets of $\mathrm{CD}^{+} \mathrm{T}$ cells. In a subsequent study of 22 healthy and preeclamptic pregnancies, disruption in Signal Transucer and Activator of Transcription (STAT)5 signaling dynamics in $\mathrm{CD}^{+} \mathrm{T}$ cells was highly associated with the later development of preeclampsia (AUC $=0.92$ ) [63]. Although larger cohorts are needed to test the boundaries of generalizability of the findings, these observations create a series of hypotheses regarding the requirement of STAT5 signaling in $\mathrm{CD}^{+} \mathrm{T}$ cells for the maintenance of a healthy human pregnancy, which dovetails with a large body of evidence from animal studies [121, 153, 154].

Circulating proteins released from immune and nonimmune cells (e.g., endothelial, trophoblast, decidual, or fetal cells) are components of the regulatory network connecting immune cells and their environment. Therefore, examination of the plasma proteome is an essential element of the multiomic analysis of maternal immune responses during normal and pathological pregnancies. The proteome is particularly advantageous as it captures information from the whole 


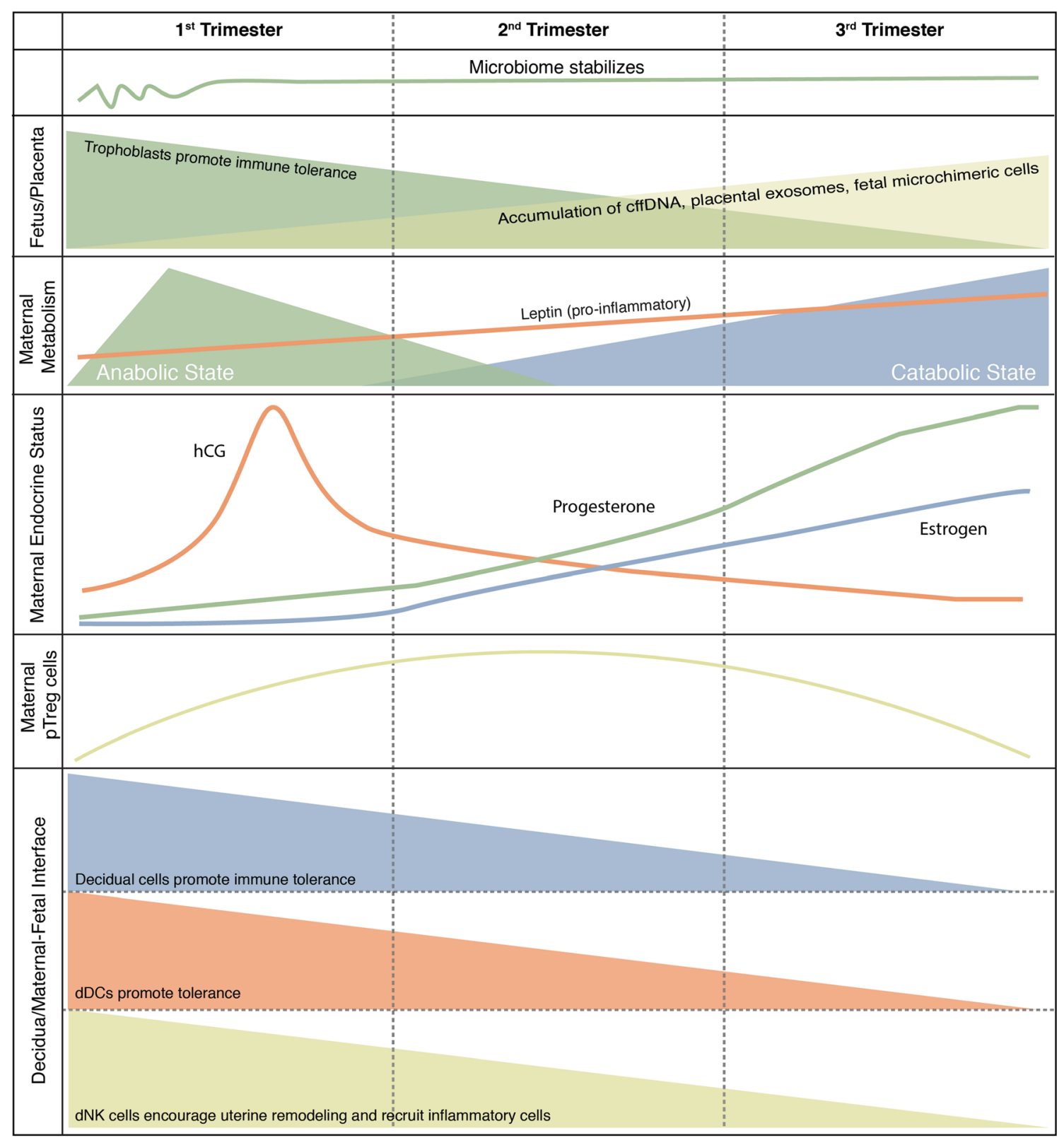

Fig. 5 Summary of the immunological timeline during pregnancy and putative immune pacemakers

body, while a considerable limitation is the inability to extrapolate the findings to the origin of the captured proteins. A significant constraint of past proteomic efforts was the limitation in the number of proteins that could simultaneously be measured in patient plasma. Recent advances in highly multiplex proteomic platforms now allow for the sensitive and simultaneous measurement of more than one thousand proteins in small biological samples $(<100 \mu \mathrm{L})[101,143]$. For example, two recent studies examining over 1,300 plasma proteins in women with normal term pregnancies revealed proteomic signatures that predicted gestational age at the time of sampling with remarkable accuracy $\left(R>0.9, p\right.$ value $\left.<10^{-14}\right)[3$, $145]$. In both studies, components of the proteomic signatures of gestation were biologically plausible and pointed at factors implicated in immune regulation, such as IL-1 receptor and modulators of the JAK/STAT pathways in T cells, for example chorionic somatomammotropin [3, 145].

While most proteomic studies of pregnancy have focused on the analysis of circulating plasma proteins, analyses of other physiological compartments, such as the amniotic fluid, have also been reported [43, 60, 61, 99, 146, 149]. Although mostly small, these studies have identified biomarkers for preterm birth in the setting of preterm labor [20, 149], preterm premature rupture of membranes [43], and cervical insufficiency [60]. In complementary proteomic studies, Cantonwine et al. assessed the proteomic content of fetalderived microparticles in the circulation [25]. This study was particularly interesting as it effectively provided a "biopsy" of 
the feto-maternal interface and a rare real time in vivo glimpse of human fetal physiology. These authors isolated microparticles from samples collected at 10 to 12 weeks' gestation and examined 132 proteins, of which a signature of 62 proteins predicted preterm birth $(\mathrm{AUC}=0.857)$. Proteins involved in inflammation, particularly the adaptive immune system and the complement system, were highly overrepresented. This work is remarkable for its ability to predict preterm birth as early as the first trimester.

While mass cytometry and proteomic approaches require the a priori selection of a restricted set of analytes (i.e., are limited by which antibodies are used for staining markers of interest or which proteins are queried), transcriptomic and metabolomic platforms can offer untargeted analyses. RNAseq technologies in particular allow the unparalleled assessment of over 20,000 gene transcripts simultaneously. With the advent of cell-free-RNA sequencing (cf-RNAseq), transcripts derived from the maternal and fetal genomes can be measured in maternal plasma, providing a tool for noninvasive monitoring of the mother and her fetus during pregnancy [85, 117]. In a hallmark study of healthy and preterm pregnancy, Ngo et al. used cf-RNAseq to define a transcriptomic clock of human pregnancy using peripheral plasma. They were able to develop a model that predicted time to delivery from plasma sample collection $(\mathrm{AUC}=0.91)$ and a second model capable of predicting preterm birth (AUC $=0.86)$ [117]. Interestingly, gene transcripts involved in the regulation of the immune system were among those most highly correlated with gestational age and time to delivery, even though many of these transcripts were not previously known to play a role in human pregnancy.

The gap between the discrete knowledge gleaned from each individual -omic technology and a holistic understanding of the many complexities and variables in the immune system leaves numerous fundamental challenges in the bioinformatics field. An integrative viewpoint that uses novel statistical modeling and computational techniques to study multiple biological technologies has yielded interesting insights that have the promise to enable inference of significant interactions across biological features. To interpret the large amount of data generated by modern multiomic tools, new computational methods in the field of machine learning have arisen to address this difficulty in the analysis of relevant modalities including cell types, signaling pathways, and protein abundance as well as gene expression profiles that contribute to the development and maintenance of both healthy and pathologic pregnancies. In a recent publication by Ghaemi et al., the authors have utilized these machine learning techniques to address human pregnancy. The approach is based on stacked generalization, a technique developed to combine multiple sets of predictions and the use of elastic net (EN) analysis [55]. EN models extend standard linear regression to highdimensional data, where there are many more features than observations (or samples) with complex inter-correlations. Among sets of features that are highly correlated, EN will choose representative features to include in the model. The result is a simplified model, which includes important predictive features. These features are represented via a rich visual network. In this particular example, EN regression was used to measure the ability of each of the seven -omic technologies investigated (cell-free transcriptomics; antibody-based cytokine measurements in plasma and serum; microbiomic analyses of vaginal swabs, stool, saliva, and tooth/gum; mass cytometric analyses of whole blood; untargeted metabolomics; and targeted proteomics analysis of plasma) to predict gestational age. Stacked generalization increased the predictive power of the combined model by accounting for the intrinsic internal correlation structure and size of each modality. Notably, strong correlations between metabolomic, proteomic, and transcriptomic features and specific immune cell signaling responses pointed at biologically plausible interactions. For example, the model identified a strong relationship between the steroid hormone pregnanolone sulfate - a derivative of progesterone - and the signaling behavior of myeloid DCs and Tregs, which begins to shed light on the mechanisms by which progesterone modulates the immune system during pregnancy. A role for IL-2 signaling and STAT5 was again highlighted, in concordance with the cytomic, proteomic, and traditional science studies noted above $[2,3]$.

\section{Conclusion}

Results of recent longitudinal and multiomic studies provide a solid basis to ultimately build a comprehensive atlas representing all biological and interlinked elements contributing to the paced immune programming during pregnancy. The integrative approach of multiomic studies holds particular promise for deriving highly predictive and biologically plausible signatures of preterm birth (Fig. 1). Importantly, such biosignatures are derived in accessible biological compartments (i.e., peripheral blood) and with technologies that can be transferred into clinical laboratories. Finally, biologically plausible signatures are most promising among all types of biomarkers to identify novel therapeutic targets. Significant investment in resource-intense and large-scale multiomic studies in diverse patient populations is an essential next step to identify and validate predictive biological signatures and novel therapeutic targets.

Funding information This study was supported by the Stanford Maternal and Child Health Research Institute, the March of Dimes Prematurity Research Center at Stanford, and the Bill and Melinda Gates Foundation. The study was also supported in part by the Charles and Marie Robertson Foundation, the Doris Duke Foundation, the Mary L. Johnson Research Fund, the Christopher Hess Research Fund, and the National Institute of Health. 


\section{Compliance with ethical standards}

Conflicts of interest D.A.R holds stock in Seres Therapeutics and Evelo Bioscences and stock options in ArcBio, Karius, NanoBio, ProdermIQ, and Second Genome. M.P.S is a cofounder and on the Scientific Advisory board of the following: Personalis, Qbio, SensOmics, January, Mirvie, and Filtricine. M.P.S is on the scientific advisory board of the following: Genapsys and Jupiter. Authors M.N.M and S.R.Q are inventors on a patent on cfRNA associated with article by Ngo et al. cited in this text (https://doi.org/10.1126/science.aar3819). S.Q. is founder, shareholder and board member of Mirvie.

Open Access This article is licensed under a Creative Commons Attribution 4.0 International License, which permits use, sharing, adaptation, distribution and reproduction in any medium or format, as long as you give appropriate credit to the original author(s) and the source, provide a link to the Creative Commons licence, and indicate if changes were made. The images or other third party material in this article are included in the article's Creative Commons licence, unless indicated otherwise in a credit line to the material. If material is not included in the article's Creative Commons licence and your intended use is not permitted by statutory regulation or exceeds the permitted use, you will need to obtain permission directly from the copyright holder. To view a copy of this licence, visit http://creativecommons.org/licenses/by/4.0/.

\section{References}

1. Aggelakopoulou M, Kourepini E, Paschalidis N, Simoes DCM, Kalavrizioti D, Dimisianos N, Papathanasopoulos P, Mouzaki A, Panoutsakopoulou V (2016) ER $\beta$-dependent direct suppression of human and murine Th17 cells and treatment of established central nervous system autoimmunity by a neurosteroid. J Immunol 197(7):2598-2609

2. Aghaeepour N, Ganio EA, Mcilwain D, Tsai AS, Tingle M et al (2017) An immune clock of human pregnancy. Sci Immunol 2(15)

3. Aghaeepour N, Lehallier B, Baca Q, Ganio EA, Wong RJ et al (2018) A proteomic clock of human pregnancy. Am J Obstet Gynecol 218(3):347.e1-347.e14

4. Ali ES, Mangold C, Peiris AN (2017) Estriol: emerging clinical benefits. Menopause. 24(9):1081-1085

5. AlSaif S, Mumtaz S, Wray S (2015) A short review of adipokines, smooth muscle and uterine contractility. Life Sci 125:2-8

6. Aluvihare VR, Kallikourdis M, Betz AG (2004) Regulatory T cells mediate maternal tolerance to the fetus. Nat Immunol 5(3): 266-271

7. Arck P, Hansen PJ, Jericevic BM, Piccinni M-P, Szekeres-Bartho J (2007) Progesterone during pregnancy: endocrine-immune cross talk in mammalian species and the role of stress. Am J Reprod Immunol 58(3):268-279

8. Arck P, Solano ME, Maciej K, Robertson S (2013) Reproductive immunology: piece by piece. J Reprod Immunol 97(1):1

9. Arck PC, Hecher K (2013) Fetomaternal immune cross-talk and its consequences for maternal and offspring's health. Nat Med 19(5):548

10. Areia A, Vale-Pereira S, Alves V, Rodrigues-Santos P, SantosRosa $\mathrm{M}$ et al (2016) Can membrane progesterone receptor $\alpha$ on $\mathrm{T}$ regulatory cells explain the ensuing human labour? J Reprod Immunol 113:22-26

11. Ariga H, Ohto H, Busch MP, Imamura S, Watson R et al (2001) Kinetics of fetal cellular and cell-free DNA in the maternal circulation during and after pregnancy: implications for noninvasive prenatal diagnosis. Transfusion 41(12):1524-1530
12. Arruvito L, Giulianelli S, Flores AC, Paladino N, Barboza M, Lanari C, Fainboim L (2008) NK cells expressing a progesterone receptor are susceptible to progesterone-induced apoptosis. J Immunol 180(8):5746-5753

13. Baker JM, Chase DM, Herbst-Kralovetz MM (2018) Uterine microbiota: residents, tourists, or invaders? Front Immunol 9

14. Bhattacharjee KG, Bhattacharyya M, Halder UC, Jana P, Sinha AK (2012) The "cross talk" between the receptors of insulin, estrogen and progesterone in neutrophils in the synthesis of maspin through nitric oxide in breast cancer. Int J Biomed Sci 8(2):129 139

15. Bhattacharjee KG, Sinha AK (2016) Insulin induced down regulation of the progesterone receptor number in neutrophils in the synthesis of maspin in breast cancer. JCPCR 4(5):1-6

16. Bianchi DW, Zickwolf GK, Weil GJ, Sylvester S, DeMaria MA (1996) Male fetal progenitor cells persist in maternal blood for as long as 27 years postpartum. Proc Natl Acad Sci U S A 93(2):705708

17. Biswas SK, Lopez-Collazo E (2009) Endotoxin tolerance: new mechanisms, molecules and clinical significance. Trends Immunol 30(10):475-487

18. Blazkova J, Gupta S, Liu Y, Gaudilliere B, Ganio EA et al (2017) Multicenter systems analysis of human blood reveals immature neutrophils in males and during pregnancy. J Immunol 1601855

19. Brown RG, Marchesi JR, Lee YS, Smith A, Lehne B et al (2018) Vaginal dysbiosis increases risk of preterm fetal membrane rupture, neonatal sepsis and is exacerbated by erythromycin. BMC Med 16

20. Bujold E, Romero R, Kusanovic JP, Erez O, Gotsch F, Chaiworapongsa T, Gomez R, Espinoza J, Vaisbuch E, Mee Kim Y, Edwin S, Pisano M, Allen B, Podust VN, Dalmasso EA, Rutherford J, Rogers W, Moser A, Yoon BH, Barder T (2008) Proteomic profiling of amniotic fluid in preterm labor using two-dimensional liquid separation and mass spectrometry. J Matern Fetal Neonatal Med 21(10):697-713

21. Burton GJ, Jauniaux E (2018) Pathophysiology of placentalderived fetal growth restriction. Am J Obstet Gynecol 218(2S): S745-S761

22. Butts CL, Bowers E, Horn JC, Shukair SA, Belyavskaya E, Tonelli L, Sternberg EM (2008) Inhibitory effects of progesterone differ in dendritic cells from female and male rodents. Gend Med 5(4):434-447

23. Callahan BJ, DiGiulio DB, Goltsman DSA, Sun CL, Costello EK, Jeganathan P, Biggio JR, Wong RJ, Druzin ML, Shaw GM, Stevenson DK, Holmes SP, Relman DA (2017) Replication and refinement of a vaginal microbial signature of preterm birth in two racially distinct cohorts of US women. Proc Natl Acad Sci U S A 114(37):9966-9971

24. Calzolari A (1898) Recherches experimentales sur un rapport probable entre la function du thimus et celle des testicules. Arch Ital Biol 30:71-89

25. Cantonwine DE, Zhang Z, Rosenblatt K, Goudy KS, Doss RC et al (2016) Evaluation of proteomic biomarkers associated with circulating microparticles as an effective means to stratify the risk of spontaneous preterm birth. Am J Obstet Gynecol 214(5): 631.e1-631.e11

26. Carp H, Dardik R, Lubetsky A, Salomon O, Eskaraev R, Rosenthal E, Inbal A (2004) Prevalence of circulating procoagulant microparticles in women with recurrent miscarriage: a case-controlled study. Hum Reprod 19(1):191-195

27. Cavanagh PC, Dunk C, Pampillo M, Szereszewski JM, Taylor JE et al (2009) Gonadotropin-releasing hormone-regulated chemokine expression in human placentation. Am J Phys Cell Phys 297(1):C17-C27

28. Chai SY, Smith R, Zakar T, Mitchell C, Madsen G (2012) Term myometrium is characterized by increased activating epigenetic 
modifications at the progesterone receptor-A promoter. Mol Hum Reprod 18(8):401-409

29. Charbonneau MR, Blanton LV, DiGiulio DB, Relman DA, Lebrilla CB, Mills DA, Gordon JI (2016) Human developmental biology viewed from a microbial perspective. Nature 535(7610): $48-55$

30. Olympe C, Shiqiu X, Ashley M (2011) Maternal KIR and fetal HLA-C: a fine balance. J Leukoc Biol 90(4):703-716

31. Chen R-Y, Fan Y-M, Zhang Q, Liu S, Li Q et al (2015) Estradiol inhibits Th17 cell differentiation through inhibition of ROR $\gamma \mathrm{T}$ transcription by recruiting the ER $\alpha /$ REA complex to estrogen response elements of the ROR $\gamma \mathrm{T}$ promoter. J Immunol 194(8): 4019-4028

32. Chen T, Darrasse-Jèze G, Bergot A-S, Courau T, Churlaud G et al (2013) Self-specific memory regulatory T cells protect embryos at implantation in mice. J Immunol 191(5):2273-2281

33. Cheng S-B, Davis S, Sharma S (2018) Maternal-fetal cross talk through cell-free fetal DNA, telomere shortening, microchimerism, and inflammation. Am J Reprod Immunol 79(5):e12851

34. Condon JC, Jeyasuria P, Faust JM, Mendelson CR (2004) Surfactant protein secreted by the maturing mouse fetal lung acts as a hormone that signals the initiation of parturition. Proc Natl Acad Sci U S A 101(14):4978-4983

35. Cong J, Zhang X (2018) How human microbiome talks to health and disease. Eur J Clin Microbiol Infect Dis 37(9):1595-1601

36. Connor KL, Chehoud C, Altrichter A, Chan L, DeSantis TZ, Lye SJ (2018) Maternal metabolic, immune, and microbial systems in late pregnancy vary with malnutrition in mice. Biol Reprod 98(4): 579-592

37. Darrasse-Jèze G, Darasse-Jèze G, Klatzmann D, Charlotte F, Salomon BL, Cohen JL (2006) CD4 + CD25+ regulatory/ suppressor $\mathrm{T}$ cells prevent allogeneic fetus rejection in mice. Immunol Lett 102(1):106-109

38. Dauven D, Ehrentraut S, Langwisch S, Zenclussen AC, Schumacher A (2016) Immune modulatory effects of human chorionic gonadotropin on dendritic cells supporting fetal survival in murine pregnancy. Front Endocrinol (Lausanne) 7:146

39. Davis MM, Tato CM, Furman D (2017) Systems immunology: just getting started. Nat Immunol 18(7):725-732

40. De Rosa V, Procaccini C, Calì G, Pirozzi G, Fontana S et al (2007) A key role of leptin in the control of regulatory $\mathrm{T}$ cell proliferation. Immunity 26(2):241-255

41. Deshmukh H, Way SS (2019) Immunological basis for recurrent fetal loss and pregnancy complications. Annu Rev Pathol 14:185210

42. DiGiulio DB, Callahan BJ, McMurdie PJ, Costello EK, Lyell DJ et al (2015) Temporal and spatial variation of the human microbiota during pregnancy. Proc Natl Acad Sci U S A 112(35):11060 11065

43. Dixon CL, Sheller-Miller S, Saade GR, Fortunato SJ, Lai A et al (2018) Amniotic fluid exosome proteomic profile exhibits unique pathways of term and preterm labor. Endocrinology 159(5):2229 2240

44. Druckmann R, Druckmann M-A (2005) Progesterone and the immunology of pregnancy. J Steroid Biochem Mol Biol 97(5):389396

45. El-Azzamy H, Balogh A, Romero R, Xu Y, LaJeunesse $\mathrm{C}$ et al (2017) Characteristic changes in decidual gene expression signature in spontaneous term parturition. J Pathol Transl Med 51(3): 264-283

46. Enninga EAL, Holtan SG, Creedon DJ, Dronca RS, Nevala WK et al (2014) Immunomodulatory effects of sex hormones: requirements for pregnancy and relevance in melanoma. Mayo Clin Proc 89(4):520-535
47. Fan HC, Blumenfeld YJ, Chitkara U, Hudgins L, Quake SR (2008) Noninvasive diagnosis of fetal aneuploidy by shotgun sequencing DNA from maternal blood. PNAS 105(42):1626616271

48. Ferreira LMR, Meissner TB, Mikkelsen TS, Mallard W, O'Donnell CW et al (2016) A distant trophoblast-specific enhancer controls HLA-G expression at the maternal-fetal interface. PNAS 113(19):5364-5369

49. Flynn CA, Helwig AL, Meurer LN (1999) Bacterial vaginosis in pregnancy and the risk of prematurity: a meta-analysis. J Fam Pract 48(11):885-892

50. Fragiadakis GK, Baca QJ, Gherardini PF, Ganio EA, Gaudilliere DK et al (2016) Mapping the fetomaternal peripheral immune system at term pregnancy. J Immunol 197(11):4482-4492

51. Frank H-G (2017) Placental development. In: Fetal and neonatal physiology, vol. 1, pp. 101-13. Philadelphia, PA: Elsevier. 5th edn.

52. Frascoli M, Coniglio L, Witt R, Jeanty C, Fleck-Derderian S et al (2018) Alloreactive fetal $\mathrm{T}$ cells promote uterine contractility in preterm labor via IFN- $\gamma$ and TNF- $\alpha$. Sci Transl Med 10(438): eaan2263

53. Fujiki Y, Johnson KL, Tighiouart H, Peter I, Bianchi DW (2008) Fetomaternal trafficking in the mouse increases as delivery approaches and is highest in the maternal lung. Biol Reprod 79(5): 841-848

54. Gaudilliere B, Angst MS, Hotchkiss RS (2017) Deep immune profiling in trauma and sepsis: flow is the way to go!*. Crit Care Med 45(9):1577-1578

55. Ghaemi MS, DiGiulio DB, Contrepois K, Callahan B, Ngo TTM et al (2019) Multiomics modeling of the immunome, transcriptome, microbiome, proteome and metabolome adaptations during human pregnancy. Bioinformatics (in press)

56. Goldenberg RL, Culhane JF, Iams JD, Romero R (2008) Epidemiology and causes of preterm birth. Lancet 371(9606): $75-84$

57. Goldman S, Weiss A, Eyali V, Shalev E (2003) Differential activity of the gelatinases (matrix metalloproteinases 2 and 9) in the fetal membranes and decidua, associated with labour. Mol Hum Reprod 9(6):367-373

58. Golightly E, Jabbour HN, Norman JE (2011) Endocrine immune interactions in human parturition. Mol Cell Endocrinol 335(1):5259

59. Goltsman DSA, Sun CL, Proctor DM, DiGiulio DB, Robaczewska A, Thomas BC, Shaw GM, Stevenson DK, Holmes SP, Banfield JF, Relman DA (2018) Metagenomic analysis with strain-level resolution reveals fine-scale variation in the human pregnancy microbiome. Genome Res 28(10):1467-1480

60. Govia RNM, Birse KD, Sepehri S, Khafipour E, Menticoglou SM, Burgener AD, Poliquin V (2018) Amniotic fluid proteomic signatures of cervical insufficiency and their association with length of latency. Am J Reprod Immunol 80(5):e13030

61. Hallingström M, Lenco J, Vajrychova M, Link M, Tambor V, Liman V, Bullarbo M, Nilsson S, Tsiartas P, Cobo T, Kacerovsky M, Jacobsson B (2016) Proteomic analysis of early mid-trimester amniotic fluid does not predict spontaneous preterm delivery. PLoS One 11(5): $\mathrm{e} 0155164$

62. Hamilton S, Oomomian Y, Stephen G, Shynlova O, Tower CL et al (2012) Macrophages infiltrate the human and rat decidua during term and preterm labor: evidence that decidual inflammation precedes labor. Biol Reprod 86(2):39

63. Han X, Ghaemi MS, Ando K, Peterson LS, Ganio EA et al (2019) Differential dynamics of the maternal immune system in healthy pregnancy and preeclampsia. Front Immunol 10:1305

64. Hanna J, Wald O, Goldman-Wohl D, Prus D, Markel G, Gazit R, Katz G, Haimov-Kochman R, Fujii N, Yagel S, Peled A, Mandelboim O (2003) CXCL12 expression by invasive 
trophoblasts induces the specific migration of CD16- human natural killer cells. Blood 102(5):1569-1577

65. Hanna N, Hanna I, Hleb M, Wagner E, Dougherty J et al (2000) Gestational age-dependent expression of IL-10 and its receptor in human placental tissues and isolated cytotrophoblasts. J Immunol 164(11):5721-5728

66. Hannan NJ, Salamonsen LA (2007) Role of chemokines in the endometrium and in embryo implantation. Curr Opin Obstet Gynecol 19(3):266-272

67. Hansen VL, Faber LS, Salehpoor AA, Miller RD (2017) A pronounced uterine pro-inflammatory response at parturition is an ancient feature in mammals. Proc Biol Sci 284(1865)

68. Hao S, Zhao J, Zhou J, Zhao S, Hu Y, Hou Y (2007) Modulation of 17 beta-estradiol on the number and cytotoxicity of NK cells in vivo related to $\mathrm{MCM}$ and activating receptors. Int Immunopharmacol 7(13):1765-1775

69. Hardy DB, Janowski BA, Corey DR, Mendelson CR (2006) Progesterone receptor plays a major antiinflammatory role in human myometrial cells by antagonism of nuclear factor-kappaB activation of cyclooxygenase 2 expression. Mol Endocrinol 20(11):2724-2733

70. Herzenberg LA, Bianchi DW, Schröder J, Cann HM, Iverson GM (1979) Fetal cells in the blood of pregnant women: detection and enrichment by fluorescence-activated cell sorting. Proc Natl Acad Sci U S A 76(3):1453-1455

71. Ișik G, Demirezen Ș, Dönmez HG, Beksaç MS (2016) Bacterial vaginosis in association with spontaneous abortion and recurrent pregnancy losses. J Cytol 33(3):135-140

72. Javadian A, Salehi E, Bidad K, Sahraian MA, Izad M (2014) Effect of estrogen on Th1, Th2 and Th17 cytokines production by proteolipid protein and PHA activated peripheral blood mononuclear cells isolated from multiple sclerosis patients. Arch Med Res 45(2):177-182

73. Jiang TT, Chaturvedi V, Ertelt JM, Kinder JM, Clark DR et al (2014) Regulatory T cells: new keys for further unlocking the enigma of fetal tolerance and pregnancy complications. J Immunol 192(11):4949-4956

74. Jimenez DF, Leapley AC, Lee CI, Ultsch M-N, Tarantal AF (2005) Fetal CD34+ cells in the maternal circulation and longterm microchimerism in rhesus monkeys (Macaca mulatta). Transplantation 79(2):142-146

75. Kane N, Kelly R, Saunders PTK, Critchley HOD (2009) Proliferation of uterine natural killer cells is induced by human chorionic gonadotropin and mediated via the mannose receptor. Endocrinology 150(6):2882-2888

76. Kavanagh DM, Kersaudy-Kerhoas M, Dhariwal RS, Desmulliez MPY (2010) Current and emerging techniques of fetal cell separation from maternal blood. J Chromatogr B Anal Technol Biomed Life Sci 878(22):1905-1911

77. Khosrotehrani K, Johnson KL, Guégan S, Stroh H, Bianchi DW (2005) Natural history of fetal cell microchimerism during and following murine pregnancy. J Reprod Immunol 66(1):1-12

78. Kim SY, Khanal D, Kalionis B, Chrzanowski W (2019) Highfidelity probing of the structure and heterogeneity of extracellular vesicles by resonance-enhanced atomic force microscopy infrared spectroscopy. Nat Protoc 14(2):576-593

79. Kinder JM, Stelzer IA, Arck PC, Way SS (2017) Immunological implications of pregnancy-induced microchimerism. Nat Rev Immunol 17(8):483

80. Kindinger LM, Bennett PR, Lee YS, Marchesi JR, Smith A et al (2017) The interaction between vaginal microbiota, cervical length, and vaginal progesterone treatment for preterm birth risk. Microbiome 5

81. King A (2000) Uterine leukocytes and decidualization. Hum Reprod Update 6(1):28-36
82. King A, Allan DS, Bowen M, Powis SJ, Joseph S, Verma S, Hiby SE, McMichael A, Loke YW, Braud VM (2000) HLA-E is expressed on trophoblast and interacts with CD94/NKG2 receptors on decidual NK cells. Eur J Immunol 30(6):1623-1631

83. King A, Gardner L, Loke YW (1996) Evaluation of oestrogen and progesterone receptor expression in uterine mucosal lymphocytes. Hum Reprod 11(5):1079-1082

84. Knight M, Redman CW, Linton EA, Sargent IL (1998) Shedding of syncytiotrophoblast microvilli into the maternal circulation in pre-eclamptic pregnancies. Br J Obstet Gynaecol 105(6):632-640

85. Koh W, Pan W, Gawad C, Fan HC, Kerchner GA et al (2014) Noninvasive in vivo monitoring of tissue-specific global gene expression in humans. Proc Natl Acad Sci U S A 111(20):73617366

86. Kohlgruber AC, LaMarche NM, Lynch L (2016) Adipose tissue at the nexus of systemic and cellular immunometabolism. Semin Immunol 28(5):431-440

87. Kohli S, Ranjan S, Hoffmann J, Kashif M, Daniel EA, al-Dabet MM, Bock F, Nazir S, Huebner H, Mertens PR, Fischer KD, Zenclussen AC, Offermanns S, Aharon A, Brenner B, Shahzad K, Ruebner M, Isermann B (2016) Maternal extracellular vesicles and platelets promote preeclampsia via inflammasome activation in trophoblasts. Blood 128(17):2153-2164

88. Koren O, Goodrich JK, Cullender TC, Spor A, Laitinen K, Bäckhed HK, Gonzalez A, Werner JJ, Angenent LT, Knight R, Bäckhed F, Isolauri E, Salminen S, Ley RE (2012) Host remodeling of the gut microbiome and metabolic changes during pregnancy. Cell 150(3):470-480

89. Kovats S, Main EK, Librach C, Stubblebine M, Fisher SJ, DeMars R (1990) A class I antigen, HLA-G, expressed in human trophoblasts. Science 248(4952):220-223

90. Krabchi K, Gros-Louis F, Yan J, Bronsard M, Massé J, Forest JC, Drouin R (2001) Quantification of all fetal nucleated cells in maternal blood between the 18th and 22nd weeks of pregnancy using molecular cytogenetic techniques. Clin Genet 60(2):145-150

91. Lash GE, Ernerudh J (2015) Decidual cytokines and pregnancy complications: focus on spontaneous miscarriage. J Reprod Immunol 108:83-89

92. Laskarin G, Tokmadzić VS, Strbo N, Bogović T, Szekeres-Bartho J, Randić L, Podack ER, Rukavina D (2002) Progesterone induced blocking factor (PIBF) mediates progesterone induced suppression of decidual lymphocyte cytotoxicity. Am J Reprod Immunol 48(4):201-209

93. Lathrop SK, Bloom SM, Rao SM, Nutsch K, Lio C-W, Santacruz N, Peterson DA, Stappenbeck TS, Hsieh CS (2011) Peripheral education of the immune system by colonic commensal microbiota. Nature 478(7368):250-254

94. Laude I, Rongières-Bertrand $\mathrm{C}$, Boyer-Neumann $\mathrm{C}$, Wolf $\mathrm{M}$, Mairovitz V, Hugel B, Freyssinet JM, Frydman R, Meyer D, Eschwège V (2001) Circulating procoagulant microparticles in women with unexplained pregnancy loss: a new insight. Thromb Haemost 85(1):18-21

95. Lee JH, Lydon JP, Kim CH (2012) Progesterone suppresses the mTOR pathway and promotes generation of induced regulatory $\mathrm{T}$ cells with increased stability. Eur J Immunol 42(10):2683-2696

96. Lee YS, Wollam J, Olefsky JM (2018) An Integrated View of Immunometabolism. Cell 172(1):22-40

97. Liu F, Guo J, Tian T, Wang H, Dong F et al (2011) Placental trophoblasts shifted Th1/Th2 balance toward Th2 and inhibited Th17 immunity at fetomaternal interface. APMIS 119(9):597-604

98. Liu S, Diao L, Huang C, Li Y, Zeng Y, Kwak-Kim JYH (2017) The role of decidual immune cells on human pregnancy. J Reprod Immunol 124:44-53

99. Liu X, Song Y, Guo Z, Sun W, Liu J (2019) A comprehensive profile and inter-individual variations analysis of the human normal amniotic fluid proteome. J Proteome 192:1-9 
100. Lo YM, Tein MS, Lau TK, Haines CJ, Leung TN et al (1998) Quantitative analysis of fetal DNA in maternal plasma and serum: implications for noninvasive prenatal diagnosis. Am J Hum Genet 62(4):768-775

101. Lundberg M, Eriksson A, Tran B, Assarsson E, Fredriksson S (2011) Homogeneous antibody-based proximity extension assays provide sensitive and specific detection of low-abundant proteins in human blood. Nucleic Acids Res 39(15):e102

102. MacIntyre DA, Chandiramani M, Lee YS, Kindinger L, Smith A et al (2015) The vaginal microbiome during pregnancy and the postpartum period in a European population. Sci Rep 5:8988

103. Mackler AM, Iezza G, Akin MR, McMillan P, Yellon SM (1999) Macrophage trafficking in the uterus and cervix precedes parturition in the mouse. Biol Reprod 61(4):879-883

104. Makris V, Daniilidis A, Koiou A, Balaouras D, Fotinakis I et al (2015) Microparticles hyperactivity in a case of intrauterine growth restriction. Clin Exp Obstet Gynecol 42(2):231-233

105. Marcellin L, Schmitz T, Messaoudene M, Chader D, Parizot C, Jacques S, Delaire J, Gogusev J, Schmitt A, Lesaffre C, BreuillerFouché M, Caignard A, Vaiman D, Goffinet F, Cabrol D, Gorochov G, Méhats C (2017) Immune modifications in fetal membranes overlying the cervix precede parturition in humans. $\mathrm{J}$ Immunol 198(3):1345-1356

106. Markovic D, Bari MF, Lu B, Vatish M, Grammatopoulos DK (2013) Corticotropin-releasing hormone interacts with interleukin- $1 \beta$ to regulate prostaglandin $\mathrm{H}$ synthase- 2 expression in human myometrium during pregnancy and labor. J Clin Endocrinol Metab 98(7):2864-2875

107. Medawar P (1953) Some immunological and endocrinological problems raised by the evolution of viviparity in vertebrates. Symp Soc Exp Biol 7:320-338

108. Mincheva-Nilsson L, Baranov V (2010) Review article: the role of placental exosomes in reproduction. Am J Reprod Immunol 63(6): $520-533$

109. Mincheva-Nilsson L, Baranov V (2014) Placenta-derived exosomes and syncytiotrophoblast microparticles and their role in human reproduction: immune modulation for pregnancy success. Am J Reprod Immunol 72(5):440-457

110. Mor G, Aldo P, Alvero AB (2017) The unique immunological and microbial aspects of pregnancy. Nat Rev Immunol 17(8):469-482

111. Mor G, Cardenas I (2010) Review article: the immune system in pregnancy: a unique complexity. Am J Reprod Immunol 63(6): 425-433

112. Mor G, Cardenas I, Abrahams V, Guller S (2011) Inflammation and pregnancy: the role of the immune system at the implantation site. Ann N Y Acad Sci 1221(1):80-87

113. Morgan TK (2018) Cell- and size-specific analysis of placental extracellular vesicles in maternal plasma and pre-eclampsia. Transl Res 201:40-48

114. Nair S, Salomon C (2018) Extracellular vesicles and their immunomodulatory functions in pregnancy. Semin Immunopathol 40(5):425-437

115. Nancy P, Siewiera J, Rizzuto G, Tagliani E, Osokine I, Manandhar P, Dolgalev I, Clementi C, Tsirigos A, Erlebacher A (2018) $\mathrm{H} 3 \mathrm{~K} 27 \mathrm{me} 3$ dynamics dictate evolving uterine states in pregnancy and parturition. J Clin Invest 128(1):233-247

116. F da S N, Michelon TF, Neumann J, LFS M, Wagner B et al (2016) High levels of circulating extracellular vesicles with altered expression and function during pregnancy. Immunobiology 221(7): $753-760$

117. Ngo TTM, Moufarrej MN, Rasmussen M-LH, Camunas-Soler J, Pan W et al (2018) Noninvasive blood tests for fetal development predict gestational age and preterm delivery. Science 360(6393): $1133-1136$

118. Oreshkova T, Dimitrov R, Mourdjeva M (2012) A cross-talk of decidual stromal cells, trophoblast, and immune cells: a prerequisite for the success of pregnancy. Am J Reprod Immunol 68(5):366-373

119. Osborn O, Olefsky JM (2012) The cellular and signaling networks linking the immune system and metabolism in disease. Nat Med 18(3):363-374

120. Osman I, Young A, Ledingham MA, Thomson AJ, Jordan F et al (2003) Leukocyte density and pro-inflammatory cytokine expression in human fetal membranes, decidua, cervix and myometrium before and during labour at term. Mol Hum Reprod 9(1):41-45

121. Owen DL, Farrar MA (2017) STAT5 and CD4 + T Cell Immunity. F1000Res. 6

122. Pallinger E, Bognar Z, Bogdan A, Csabai T, Abraham H, Szekeres-Bartho J (2018) PIBF+ extracellular vesicles from mouse embryos affect IL-10 production by CD8+ cells. Sci Rep 8

123. Pearce EJ, Pearce EL (2017) Immunometabolism in 2017: driving immunity: all roads lead to metabolism. Nat Rev Immunol https:// www.nature.com/articles/nri.2017.139

124. Pearce EJ, Pearce EL (2018) Driving immunity: all roads lead to metabolism. Nat Rev Immunol 18(2):81-82

125. Penn AA (2017) Endocrine and paracrine function of the human placenta. In: Fetal and neonatal physiology, vol. 1, pp. 134-44. Philadelphia, PA: Elsevier. 5th edn.

126. Perez-Muñoz ME, Arrieta M-C, Ramer-Tait AE, Walter J (2017) A critical assessment of the "sterile womb" and "in utero colonization" hypotheses: implications for research on the pioneer infant microbiome. Microbiome. 5(1):48

127. Pérez-Pérez A, Vilariño-García T, Fernández-Riejos P, MartínGonzález J, Segura-Egea JJ, Sánchez-Margalet V (2017) Role of leptin as a link between metabolism and the immune system. Cytokine Growth Factor Rev 35:71-84

128. Peters GA, Yi L, Skomorovska-Prokvolit Y, Patel B, Amini P et al (2017) Inflammatory stimuli increase progesterone receptor-a stability and transrepressive activity in myometrial cells. Endocrinology 158(1):158-169

129. Polanczyk MJ, Carson BD, Subramanian S, Afentoulis M, Vandenbark AA et al (2004) Cutting edge: estrogen drives expansion of the CD $4+\mathrm{CD} 25+$ regulatory $\mathrm{T}$ cell compartment. J Immunol 173(4):2227-2230

130. Polanczyk MJ, Hopke C, Vandenbark AA, Offner H (2006) Estrogen-mediated immunomodulation involves reduced activation of effector T cells, potentiation of Treg cells, and enhanced expression of the PD-1 costimulatory pathway. J Neurosci Res 84(2):370-378

131. Polese B, Gridelet V, Araklioti E, Martens H, Perrier d'Hauterive S, Geenen V (2014) The endocrine milieu and CD4 T-lymphocyte polarization during pregnancy. Front Endocrinol (Lausanne) 5

132. Polgar B, Barakonyi B, Xynos I, Szekeres-Bartho J (1999) The role of $\gamma / \delta \mathrm{T}$ cell receptor positive cells in pregnancy. Am $\mathrm{J}$ Reprod Immunol 41(4):239-244

133. Poloski E, Oettel A, Ehrentraut S, Luley L, Costa SD et al (2016) JEG-3 trophoblast cells producing human chorionic gonadotropin promote conversion of human CD4 + FOXP3 - T cells into CD4 + FOXP3+ regulatory $\mathrm{T}$ cells and foster $\mathrm{T}$ cell suppressive activity. Biol Reprod 94(5):106

134. Prieto GA, Rosenstein Y (2006) Oestradiol potentiates the suppressive function of human CD4 CD25 regulatory T cells by promoting their proliferation. Immunology 118(1):58-65

135. Prince AL, Antony KM, Chu DM, Aagaard KM (2014) The microbiome, parturition, and timing of birth: more questions than answers. J Reprod Immunol 0:12-19

136. Prince AL, Ma J, Kannan PS, Alvarez M, Gisslen T et al (2016) The placental membrane microbiome is altered among subjects with spontaneous preterm birth with and without chorioamnionitis. Am J Obstet Gynecol 214(5):627.e1-627.e16

137. Radu CM, Campello E, Spiezia L, Dhima S, Visentin S, Gavasso S, Woodhams B, Cosmi E, Simioni P (2015) Origin and levels of 
circulating microparticles in normal pregnancy: a longitudinal observation in healthy women. Scand J Clin Lab Invest 75(6):487495

138. Reis BS, Lee K, Fanok MH, Mascaraque C, Amoury M, Cohn LB, Rogoz A, Dallner OS, Moraes-Vieira PM, Domingos AI, Mucida D (2015) Leptin receptor signaling in T cells is required for Th17 differentiation. J Immunol 194(11):5253-5260

139. Ren L, Liu Y-Q, Zhou W-H, Zhang Y-Z (2012) Trophoblastderived chemokine CXCL12 promotes CXCR4 expression and invasion of human first-trimester decidual stromal cells. Hum Reprod 27(2):366-374

140. Renthal NE, Williams KC, Mendelson CR (2013) MicroRNAsmediators of myometrial contractility during pregnancy and labour. Nat Rev Endocrinol 9(7):391-401

141. Rijnink EC, Penning ME, Wolterbeek R, Wilhelmus S, Zandbergen $\mathrm{M}$ et al (2015) Tissue microchimerism is increased during pregnancy: a human autopsy study. Mol Hum Reprod 21(11):857-864

142. Rinaldi SF, Makieva S, Saunders PT, Rossi AG, Norman JE (2017) Immune cell and transcriptomic analysis of the human decidua in term and preterm parturition. Mol Hum Reprod 23(10):708-724

143. Rohloff JC, Gelinas AD, Jarvis TC, Ochsner UA, Schneider DJ et al (2014) Nucleic acid ligands with protein-like side chains: modified aptamers and their use as diagnostic and therapeutic agents. Mol Ther Nucleic Acids 3:e201

144. Romero R, Dey SK, Fisher SJ (2014) Preterm labor: one syndrome, many causes. Science 345(6198):760-765

145. Romero R, Erez O, Maymon E, Chaemsaithong P, Xu Z et al (2017) The maternal plasma proteome changes as a function of gestational age in normal pregnancy: a longitudinal study. Am J Obstet Gynecol 217(1):67.e1-67.e21

146. Romero R, Espinoza J, Rogers WT, Moser A, Nien JK, Kusanovic JP, Gotsch F, Erez O, Gomez R, Edwin S, Hassan SS (2008) Proteomic analysis of amniotic fluid to identify women with preterm labor and intra-amniotic inflammation/infection: the use of a novel computational method to analyze mass spectrometric profiling. J Matern Fetal Neonatal Med 21(6):367-388

147. Romero R, Hassan SS, Gajer P, Tarca AL, Fadrosh DW et al (2014) The composition and stability of the vaginal microbiota of normal pregnant women is different from that of nonpregnant women. Microbiome 2(1):4

148. Romero R, Hassan SS, Gajer P, Tarca AL, Fadrosh DW et al (2014) The vaginal microbiota of pregnant women who subsequently have spontaneous preterm labor and delivery and those with a normal delivery at term. Microbiome 2:18

149. Romero R, Kusanovic JP, Gotsch F, Erez O, Vaisbuch E et al (2010) Isobaric labeling and tandem mass spectrometry: a novel approach for profiling and quantifying proteins differentially expressed in amniotic fluid in preterm labor with and without intra-amniotic infection/inflammation. J Matern Fetal Neonatal Med 23(4):261-280

150. Romero R, Espinoza J, Kusanovic JP, Gotsch F, Hassan S et al (2006) The preterm parturition syndrome. BJOG Int J Obstet Gynaecol 113(s3):17-42

151. Romero R, Xu Y, Plazyo O, Chaemsaithong P, Chaiworapongsa T, Unkel R, Than NG, Chiang PJ, Dong Z, Xu Z, Tarca AL, Abrahams VM, Hassan SS, Yeo L, Gomez-Lopez N (2018) A role for the inflammasome in spontaneous labor at term. Am J Reprod Immunol 79(6):e12440

152. Rose SMS-F, Contrepois K, Moneghetti KJ, Zhou W, Mishra T et al (2019) A longitudinal big data approach for precision health. Nat Med 25(5):792

153. Rowe JH, Ertelt JM, Aguilera MN, Farrar MA, Way SS (2011) Foxp3+ regulatory $\mathrm{T}$ cell expansion required for sustaining pregnancy compromises host defense against prenatal bacterial pathogens. Cell Host Microbe 10(1):54-64

154. Rowe JH, Ertelt JM, Xin L, Way SS (2012) Pregnancy imprints regulatory memory that sustains anergy to fetal antigen. Nature. 490(7418):102-106

155. Russell DG, Huang L, VanderVen BC (2019) Immunometabolism at the interface between macrophages and pathogens. Nat Rev Immunol (in press)

156. Salamone G, Fraccaroli L, Gori S, Grasso E, Paparini D, Geffner J, Pérez Leirós C, Ramhorst R (2012) Trophoblast cells induce a tolerogenic profile in dendritic cells. Hum Reprod 27(9):2598_ 2606

157. Salimi S, Farajian-Mashhadi F, Naghavi A, Mokhtari M, Shahrakipour M et al (2014) Different profile of serum leptin between early onset and late onset preeclampsia. Dis Markers

158. Salomon C, Torres MJ, Kobayashi M, Scholz-Romero K, Sobrevia L et al (2014) A gestational profile of placental exosomes in maternal plasma and their effects on endothelial cell migration. PLoS One 9(6)

159. Samstein RM, Josefowicz SZ, Arvey A, Treuting PM, Rudensky AY (2012) Extrathymic generation of regulatory T cells in placental mammals mitigates maternal-fetal conflict. Cell 150(1):29-38

160. Sarker S, Scholz-Romero K, Perez A, Illanes SE, Mitchell MD et al (2014) Placenta-derived exosomes continuously increase in maternal circulation over the first trimester of pregnancy. J Transl Med:12

161. Sasaki Y, Sakai M, Miyazaki S, Higuma S, Shiozaki A, Saito S (2004) Decidual and peripheral blood CD4+ CD25+ regulatory T cells in early pregnancy subjects and spontaneous abortion cases. Mol Hum Reprod 10(5):347-353

162. Schumacher A (2017) Human chorionic gonadotropin as a pivotal endocrine immune regulator initiating and preserving fetal tolerance. Int J Mol Sci 18(10)

163. Schumacher A, Heinze K, Witte J, Poloski E, Linzke N, Woidacki $\mathrm{K}$, Zenclussen AC (2013) Human chorionic gonadotropin as a central regulator of pregnancy immune tolerance. J Immunol 190(6):2650-2658

164. Segerer SE, Müller N, van den Brandt J, Kapp M, Dietl J et al (2009) Impact of female sex hormones on the maturation and function of human dendritic cells. Am J Reprod Immunol 62(3): $165-173$

165. Shah NM, Herasimtschuk AA, Boasso A, Benlahrech A, Fuchs D et al (2017) Changes in T cell and dendritic cell phenotype from mid to late pregnancy are indicative of a shift from immune tolerance to immune activation. Front Immunol 8

166. Smith PM, Howitt MR, Panikov N, Michaud M, Gallini CA et al (2013) The microbial metabolites, short-chain fatty acids, regulate colonic Treg cell homeostasis. Science 341(6145):569-573

167. Somerset DA, Zheng Y, Kilby MD, Sansom DM, Drayson MT (2004) Normal human pregnancy is associated with an elevation in the immune suppressive $\mathrm{CD} 25+\mathrm{CD} 4+$ regulatory T-cell subset. Immunology 112(1):38-43

168. Sun Y, Li H, Sun M-J, Zheng Y-Y, Gong D-J, Xu Y (2014) Endotoxin tolerance induced by lipopolysaccharides derived from Porphyromonas gingivalis and Escherichia coli: alternations in Toll-like receptor 2 and 4 signaling pathway. Inflammation 37(1):268-276

169. Svensson-Arvelund J, Ernerudh J, Buse E, Cline JM, Haeger J-D et al (2014) The placenta in toxicology. Part II: systemic and local immune adaptations in pregnancy. Toxicol Pathol 42(2):327-338

170. Svensson-Arvelund J, Mehta RB, Lindau R, Mirrasekhian E, Rodriguez-Martinez H et al (2015) The human fetal placenta promotes tolerance against the semiallogeneic fetus by inducing regulatory T cells and homeostatic M2 macrophages. J Immunol 194(4):1534-1544 
171. Szekeres-Bartho J (2018) The role of progesterone in the FetoMaternal Immunological Crosstalk. MPP

172. Szekeres-Bartho J, Barakonyi A, Miko E, Polgar B, Palkovics T (2001) The role of gamma/delta T cells in the feto-maternal relationship. Semin Immunol 13(4):229-233

173. Szekeres-Bartho J, Polgar B (2010) PIBF: the double edged sword. Pregnancy and tumor. Am J Reprod Immunol 64(2):77-86

174. Tabatabaei N, Eren AM, Barreiro LB, Yotova V, Dumaine A, Allard C, Fraser WD (2019) Vaginal microbiome in early pregnancy and subsequent risk of spontaneous preterm birth: a casecontrol study. BJOG 126(3):349-358

175. Taddei CR, Cortez RV, Mattar R, Torloni MR, Daher S (2018) Microbiome in normal and pathological pregnancies: a literature overview. Am J Reprod Immunol 80(2):e12993

176. Tai P, Wang J, Jin H, Song X, Yan J, Kang Y, Zhao L, An X, du X, Chen X, Wang S, Xia G, Wang B (2008) Induction of regulatory T cells by physiological level estrogen. J Cell Physiol 214(2):456464

177. Tan H, Yi L, Rote NS, Hurd WW, Mesiano S (2012) Progesterone receptor-A and -B have opposite effects on proinflammatory gene expression in human myometrial cells: implications for progesterone actions in human pregnancy and parturition. J Clin Endocrinol Metab 97(5):E719-E730

178. Tannetta D, Dragovic R, Alyahyaei Z, Southcombe J (2014) Extracellular vesicles and reproduction-promotion of successful pregnancy. Cell Mol Immunol 11(6):548-563

179. Than NG, Romero R, Tarca AL, Kekesi KA, Xu Y et al (2018) Integrated systems biology approach identifies novel maternal and placental pathways of preeclampsia. Front Immunol:9

180. Thaxton JE, Romero R, Sharma S (2009) TLR9 activation coupled to IL-10 deficiency induces adverse pregnancy outcomes. J Immunol 183(2):1144-1154

181. Thiele K, Diao L, Arck PC (2017) Immunometabolism, pregnancy, and nutrition. Semin Immunopathol:1-18

182. Thiele K, Hierweger AM, Riquelme JIA, Solano ME, Lydon JP, Arck PC (2019) Impaired progesterone-responsiveness of $\mathrm{CD} 11 \mathrm{c}+$ dendritic cells affects the generation of CD4+ regulatory $\mathrm{T}$ cells and is associated with intrauterine growth restriction in mice. Front Endocrinol (Lausanne) 10

183. Thomson AJ, Telfer JF, Young A, Campbell S, Stewart CJ et al (1999) Leukocytes infiltrate the myometrium during human parturition: further evidence that labour is an inflammatory process. Hum Reprod 14(1):229-236

184. Tsampalas M, Gridelet V, Berndt S, Foidart J-M, Geenen V, Perrier d'Hauterive S (2010) Human chorionic gonadotropin: a hormone with immunological and angiogenic properties. J Reprod Immunol 85(1):93-98

185. Tuckey RC (2005) Progesterone synthesis by the human placenta. Placenta 26(4):273-281

186. Valor L, Teijeiro R, Aristimuño C, Faure F, Alonso B, de Andrés C, Tejera M, López-Lazareno N, Fernández-Cruz E, SánchezRamón S (2011) Estradiol-dependent perforin expression by human regulatory T-cells. Eur J Clin Investig 41(4):357-364
187. van Boeckel SR, Davidson DJ, Norman JE, Stock SJ (2018) Cellfree fetal DNA and spontaneous preterm birth. Reproduction 155(3):R137-R145

188. Waldorf KMA, Singh N, Mohan AR, Young RC, Ngo L et al (2015) Uterine overdistention induces preterm labor mediated by inflammation: observations in pregnant women and nonhuman primates. Am J Obstet Gynecol 213(6):830.e1-830.e19

189. Walsh SW, Chumble AA, Washington SL, Archer KJ, Sahingur SE, Strauss JF (2017) Increased expression of toll-like receptors 2 and 9 is associated with reduced DNA methylation in spontaneous preterm labor. J Reprod Immunol 121:35-41

190. Wang W-J, Liu F-J, Xin-Liu, Hao C-F, Bao H-C et al (2014) Adoptive transfer of pregnancy-induced CD4+CD25+ regulatory $\mathrm{T}$ cells reverses the increase in abortion rate caused by interleukin 17 in the CBA/JxBALB/c mouse model. Hum Reprod 29(5):946952

191. Woidacki K, Meyer N, Schumacher A, Goldschmidt A, Maurer M, Zenclussen AC (2015) Transfer of regulatory T cells into abortion-prone mice promotes the expansion of uterine mast cells and normalizes early pregnancy angiogenesis. Sci Rep 5:13938

192. Wu H-X, Jin L-P, Xu B, Liang S-S, Li D-J (2014) Decidual stromal cells recruit Th17 cells into decidua to promote proliferation and invasion of human trophoblast cells by secreting IL-17. Cell Mol Immunol 11(3):253-262

193. Wu M, Chen C, Wang Z, Bachman H, Ouyang Y et al (2019) Separating extracellular vesicles and lipoproteins via acoustofluidics. Lab Chip 19(7):1174-1182

194. Wu X, Jin L-P, Yuan M-M, Zhu Y, Wang M-Y, Li D-J (2005) Human first-trimester trophoblast cells recruit CD56brightCD16c NK cells into decidua by way of expressing and secreting of CXCL12/stromal cell-derived factor 1. J Immunol 175(1):61-68

195. Zakar T, Hertelendy F (2007) Progesterone withdrawal: key to parturition. Am J Obstet Gynecol 196(4):289-296

196. Zang YCQ, Halder JB, Hong J, Rivera VM, Zhang JZ (2002) Regulatory effects of estriol on $\mathrm{T}$ cell migration and cytokine profile: inhibition of transcription factor NF-kappa B. J Neuroimmunol 124(1-2):106-114

197. Zenclussen AC, Gerlof K, Zenclussen ML, Sollwedel A, Bertoja AZ et al (2005) Abnormal T-cell reactivity against paternal antigens in spontaneous abortion. Am J Pathol 166(3):811-822

198. Zeng Z, Liu F, Li S (2017) Metabolic adaptations in pregnancy: a review. ANM 70(1):59-65

199. Zhao L, Shao Q, Zhang Y, Zhang L, He Y et al (2016) Human monocytes undergo functional re-programming during differentiation to dendritic cell mediated by human extravillous trophoblasts. Sci Rep:6

200. Zhou W-H, Du M-R, Dong L, Yu J, Li D-J (2008) Chemokine CXCL12 promotes the cross-talk between trophoblasts and decidual stromal cells in human first-trimester pregnancy. Hum Reprod 23(12):2669-2679

Publisher's note Springer Nature remains neutral with regard to jurisdictional claims in published maps and institutional affiliations. 